\title{
Fluoxetine induces direct inhibitory effects on mesenchymal stem cell-derived osteoprogenitor cells independent of serotonin concentration
}

\author{
SAMAR M. KOURA ${ }^{1 *}$, MOHAMED SALAMA $^{1,2^{*}}$, MAHMOUD EL-HUSSINY $^{2}$, \\ MAHMOUD EL-SAYED AWAD KHALIL ${ }^{1}$, AHMED LOTFY ${ }^{3}$, SAMIA AHMED HASSAN ${ }^{1}$, \\ SEHAM ALY GAD ELHAK ${ }^{1}$ and MOHAMED A. SOBH ${ }^{4}$ \\ ${ }^{1}$ Forensic Medicine and Clinical Toxicology Department; ${ }^{2}$ Medical Experimental Research Center, \\ Faculty of Medicine, Mansoura University, Mansoura 35516; ${ }^{3}$ Biotechnology and Life Sciences Department, \\ Faculty of Postgraduate Studies for Advanced Sciences, Beni Suef University, Beni Suef 62511; \\ ${ }^{4}$ Urology and Nephrology Center, Faculty of Medicine, Mansoura University, Mansoura 35516, Egypt
}

Received November 3, 2017; Accepted June 26, 2018

DOI: $10.3892 / \mathrm{mmr} .2019 .9924$

\begin{abstract}
Selective serotonin reuptake inhibitors are the most commonly prescribed antidepressants worldwide, which have been reported to exert potential detrimental effects on bone mineral density and increase the risk of developing fractures. The present study aimed to investigate the pathways underlying the negative effects of fluoxetine on bone using mesenchymal stem cells (MSCs) derived from rat adipose tissue as a source of osteoprogenitor cells. MSCs were harvested from adipose tissue using a collagenase enzyme digestion method and were allowed to differentiate into osteoprogenitor cells. Various concentrations of fluoxetine were added to the cells, which were harvested and analyzed by flow cytometry to detect apoptotic markers Annexin V and caspase-3, in order to assess the levels of apoptosis. The levels of endogenous serotonin released in the extracellular matrix were measured using a serotonin ELISA kit. The underlying molecular pathways associated with the effects of fluoxetine on bone were investigated with reverse transcription-quantitative polymerase chain reaction. The results of the present study revealed a significant dose-dependent increase in apoptosis in response to increasing doses of fluoxetine, which was independent of serotonin levels in the culture supernatant. These findings indicated that fluoxetine exerted a direct inhibitory effect on bone cells via an apoptosis-dependent pathway. Furthermore,
\end{abstract}

Correspondence to: Dr Mohamed Salama, Medical Experimental Research Center, Faculty of Medicine, Mansoura University, El-Gomhourya Street, Mansoura 35516, Egypt

E-mail: toxicsalama@hotmail.com

*Contributed equally

Key words: fluoxetine, serotonin, apoptosis, mesenchymal stem cells, serotonergic genes the expression levels of serotonergic genes, including serotonin $1 \mathrm{~B}$ receptor, serotonin $2 \mathrm{~A}$ receptor (HTR2A), serotonin $2 \mathrm{~B}$ receptor and serotonin transporter, were down regulated; of these genes, HTR2A exhibited the highest expression levels. Further in vitro and in vivo studies are required to verify this association and to determine the molecular pathways involved in fluoxetine-induced bone loss. Fluoxetine-induced apoptosis of osteoprogenitor cells may be the mechanism underlying the increased incidence of bone loss observed in patients treated with fluoxetine.

\section{Introduction}

Selective serotonin/5-hydroxytryptamine (5-HT) reuptake inhibitors (SSRIs) are considered first-line therapy for the treatment of depression and account for $\sim 60 \%$ of all antidepressant drugs prescribed worldwide (1). These therapeutic agents are prescribed for numerous psychiatric conditions, including post-traumatic stress, generalized anxiety, panic and premenstrual dysphoric disorders. In addition, they can be prescribed for certain non-psychiatric conditions, including chronic pain, fibromyalgia and post-menopausal vasomotor symptoms, such as night sweats and hot flashes (2). SSRIs act by antagonizing the 5-HT transporter (5HTT; also known as SLC6A4), enhancing the amount of 5-HT available in the synaptic cleft and potentiating serotonergic activity, thereby improving the symptoms of major depressive disorders (3).

A functional 5-HT signaling pathway was identified in bone in 2001 (4,5). A serotonin transporter has been detected in all major bone cell types, including osteoblasts, osteocytes and osteoclasts. Further investigation of this peripheral 5-HT system revealed that SSRIs affect the serotonin transporter in the central nervous system and bone with similar potency (6).

A dose-dependent increase in fracture risk and low bone mass has been reported to be associated with SSRI administration and the reason for these effects is unknown; however, direct and/or indirect 5-HT effects on bone cells may be the underlying cause (7). Osteoporosis results in a 
biomechanically weakened skeleton; delays in bone healing resulting from medications, such as SSRIs, may increase the chance of prosthesis implant failure and may result in suboptimal outcomes (8).

The aim of the present study was to assess the mechanisms underlying SSRI fluoxetine toxicity on mesenchymal stem cells (MSCs) osteogenesis in vitro by measuring the concentration of serotonin expressed in osteoblasts following the administration of fluoxetine. In addition, the molecular pathways associated with the toxic effects of fluoxetine on bone cells were investigated by assessing the expression of specific genes. Additionally, the extent of apoptosis occurring in bone cells in response to various concentrations of fluoxetine was evaluated.

\section{Materials and methods}

Ethics statement and animals. The present study was conducted at the Medical Experimental Research Center (MERC), Faculty of Medicine, Mansoura University (Mansoura, Egypt). The protocol conducted in the present study was approved by the medical ethical committee of the Faculty of Medicine, Mansoura University.

Adipose tissue samples were collected from 12 male Sprague Dawley rats (6-8 weeks old, 250-280 g), which were purchased from the animal house at the MERC. The animals were housed at $24 \pm 2^{\circ} \mathrm{C}, 60 \pm 10 \%$ relative humidity with a 12 -h light/dark cycle. The rats were acclimated to the laboratory conditions, fed standard rat chow and water was available ad libitum. The tissues were collected under the supervision of a responsible veterinary doctor. The samples were collected in the operating room under complete aseptic conditions, and subcutaneous, intra-abdominal and peri-renal fat samples were obtained. The samples were preserved in sterile glass bottles containing PBS (Sigma Aldrich; Merck KGaA, Darmstadt, Germany) and immediately transferred to the Stem Cell Laboratory (MERC) for processing.

Sample preparation procedures. Sample preparation was performed as described previously (9). The samples were washed numerous times with PBS supplemented with 10,000 units penicillin, $10 \mathrm{mg} / \mathrm{ml}$ streptomycin and $25 \mu \mathrm{g}$ amphotericin B per $\mathrm{ml}$. The samples were then sectioned into small pieces $\left(1 \mathrm{~mm}^{3}\right)$ and treated with collagenase type I (Gibco; Thermo Fisher Scientific, Inc., Waltham, MA, USA). An adequate amount of the enzyme $(0.05 \% \mathrm{w} / \mathrm{v})$ was added to the chopped fat tissue for $5 \mathrm{~min}$ and occasionally swirled in a water bath at $37^{\circ} \mathrm{C}$. The action of the enzyme was terminated using Dulbecco's modified Eagle's medium (DMEM)-low glucose media supplemented with $10 \%$ fetal bovine serum (FBS; both Sigma Aldrich; Merck KGaA) and $1 \%$ of penicillin/streptomycin/amphotericin; the suspension was then centrifuged at $200 \mathrm{x} \mathrm{g}$ and $4^{\circ} \mathrm{C}$ for $10 \mathrm{~min}$. Subsequently, the top oily layer was discarded and the remaining fluid was filtered through a 70- $\mu \mathrm{m}$ filter and centrifuged at $200 \mathrm{x} \mathrm{g}$ and $4^{\circ} \mathrm{C}$ for $10 \mathrm{~min}$. Cell viability was assessed using a Trypan blue exclusion assay. Cell viability was calculated as the number of viable cells divided by the total number of cells within the grids on the hemocytometer. If the cells took up trypan blue, they were considered non-viable. First the cell density of the cell line suspension was determined using a hemocytometer. Then, $0.4 \%$ solution of trypan blue in PBS was prepared, $\mathrm{pH}$ 7.2 to 7.3 . A total of $0.1 \mathrm{ml}$ trypan blue stock solution was added to $0.1 \mathrm{ml}$ cells. The hemocytometer was loaded and the cells were examined immediately under light microscope at low magnification. Cell counting was done by counting the number of blue staining cells and the number of total cells. (\% viable cells $=[1.00-($ Number of blue cells $\div$ Number of total cells)] x100). The number of viable cells per ml culture was calculated using the formula below:

Number of viable cells $\times 10^{4} \times 1.1=$ cells $/ \mathrm{ml}$ culture and cell count was $1 \times 10^{6}$ cells $/ \mathrm{mg}$ tissue.

Cells were cultured in Dulbecco's modified Eagle's medium (DMEM)-low glucose media (Sigma Aldrich; Merck $\mathrm{KGaA}$ ) supplemented with $10 \% \mathrm{FBS}, 10,000 \mathrm{U}$ penicillin and $10 \mathrm{mg} / \mathrm{ml}$ streptomycin, in two $75-\mathrm{cm}^{2}$ tissue culture flasks and maintained in an incubator at $37^{\circ} \mathrm{C}$ containing $5 \% \mathrm{CO}_{2}$. Cells were harvested once confluence reached $80 \%$ and cells from passage 3 were used for flow cytometric analysis.

As described by Zimmerlin et al (10), flow cytometric analysis was conducted to detect cellular expression of mouse anti-cluster of differentiation (CD)106 (cat. no. BBA5), anti-CD166 (cat. no. MAB6561), anti-CD146 (cat. no. MAB932), anti-CD105 (cat. no. MAB10971), anti-CD44 (cat. no. BBA10), anti-CD19 (cat. number MAB4867), anti-CD45 (cat.no. MAB1430), anti-CD90 (cat. no. MAB2067) and anti-Stro-1 (cat. no. MAB1038). The monoclonal antibodies (R\&D Systems, Inc., Minneapolis, MN, USA) were conjugated to fluorescence isothiocyanate (FITC); for each marker, $90 \mu 1$ of the cell suspension was added to $10 \mu \mathrm{l}$ of antibody (dilution 1:10) and the cells were incubated for $30 \mathrm{~min}$ in dark at room temperature with the antibodies [Secondary developing reagent (cat. no. F0103B), Flow Cytometry Staining Buffer (R\&D Systems, Inc.; cat. no. FC001) and isotype controls (R\&D Systems, Inc.; cat. nos. MAB002 and MAB003; Caltag ${ }^{\circledR}$; cat. no. MGM00]. Sterile PBS was used as a washing agent.

Osteogenic differentiation. Cells from passage 3 were seeded in 6 -well plates at a density of $5 \times 10^{4}$ cells/well. Following $24 \mathrm{~h}$, the media were replaced with osteogenic media, which consisted of DMEM-low glucose media supplemented with $10 \%$ FBS, 100 units penicillin/ml, $100 \mathrm{mg}$ streptomycin/ml, $10 \mathrm{mM}$ b-glycerophosphate, $50 \mathrm{mg} / \mathrm{ml}$ 2-phosphate ascorbate and $10 \mathrm{nM}$ dexamethasone (11). After 1 week, the cells were stained for calcium deposits using Alizarin red (Sigma Aldrich; Merck KGaA) for $30 \mathrm{~min}$ at room temperature in the dark. In addition to osteogenic differentiation, adipogenic differentiation was conducted to confirm multilineage differentiation potency of this population. Cells from passage 3 were seeded in 6 -well plates at a density of $5 \times 10^{4}$ cells/well. After $24 \mathrm{~h}$, the media were replaced with adipogenic media, which consisted of DMEM-low glucose media supplemented with $10 \%$ FBS, with 10,000 units penicillin, $10 \mathrm{mg} / \mathrm{ml}$ streptomycin, $0.5 \mu \mathrm{mol} / 1$ isobutylmethylxanthine $(1,000 \times 0.5 \mathrm{mM}$ in methanol), $50 \mu \mathrm{mol} / 1$ indomethacin $(1,000 \times 50 \mathrm{mM}$ in methanol), and $0.5 \mu \mathrm{mol} / 1$ dexamethasone $(1,000 \times 0.5 \mathrm{mM}$ in water; all from Sigma-Aldrich; Merck KGaA) (12). The medium was changed every 3 days; after 2 weeks, cytoplasmic oil droplets 
were assessed via Oil Red O staining (20 min in dark at room temperature).

Drug application. Fluoxetine hydrochloride (Eli Lilly, Patheon France, France) was added to the media at the following concentrations: $0.5,0.8,1,3,5,7,10,20$ and $30 \mu \mathrm{mol} / 1$ for 5 days at $37^{\circ} \mathrm{C}$ with $5 \% \mathrm{CO}_{2}$, and the media were replaced on days 0 and 3 . Cells cultured in drug-free medium were considered the control group. Morphological alterations were observed at day 5 in all plates using an inverted microscope (Olympus Corporation, Tokyo, Japan) and the cells were analyzed by flow cytometry to detect the apoptotic markers Annexin V and caspase-3.

\section{Detection of apoptosis}

Annexin $V$ analysis. A total of $1 \times 10^{5}$ cells from all groups were stained with propidium iodide (PI) and FITC Annexin V (BD Pharmingen; BD Biosciences, Franklin Lakes, NJ, USA). Briefly, $100 \mu \mathrm{l}$ cell suspension was incubated with $5 \mu \mathrm{l}$ FITC Annexin V and $5 \mu \mathrm{l}$ PI in the dark for $15 \mathrm{~min}$ at room temperature; $400 \mu \mathrm{l}$ binding buffer was added immediately prior to flow cytometric analysis using BD Accuri C6 software (BD Pharmingen; BD Biosciences).

Caspase-3 analysis. Briefly, the cells were washed twice with PBS, and $1 \times 10^{5}$ cells from each group were incubated with $10 \mu 1$ anti-caspase-3 conjugated to FITC (BD Pharmingen; BD Biosciences) in the dark for $20 \mathrm{~min}$ at room temperature. The cells were washed again with PBS, centrifuged for $5 \mathrm{~min}$ at $560 \mathrm{x} g$ at $22-25^{\circ} \mathrm{C}$, stained with the FITC rabbit anti-active caspase-3 antibody for $30 \mathrm{~min}$ at room temperature, then washed, and suspended in BD Perm/Wash ${ }^{\mathrm{TM}}$ buffer (component of cat. no. 554714) before analyzing by flow cytometry Accuri C6 software (BD Pharmingen; BD Biosciences).

Quantitative assessment of serotonin. The levels of serotonin present in the groups treated with various concentrations of fluoxetine and in the control group were assessed using al serotonin ELISA kit (H0533; Glory Science Co., Ltd., Shanghai, China) according to the manufacturer's protocols. The culture supernatants were collected from the plates and preserved for ELISA. The samples were prepared by diluting 5-fold with a sample dilution reagent. The wells were covered with adhesive strips and incubated for $30 \mathrm{~min}$ at $37^{\circ} \mathrm{C}$. Following incubation, the adhesive strips were removed, the liquids (the sample tested and the standards for washing) were discarded, the wells were manually washed five times, each with the diluted wash solution and horseradish peroxidase was added to each well except the blank. Subsequently, the wells were incubated again for $30 \mathrm{~min}$ at $37^{\circ} \mathrm{C}$. Following incubation, the wells were washed again and $50 \mu \mathrm{l}$ chromogen solution $\mathrm{A}$ and chromogen solution B were added to all wells and incubated for $15 \mathrm{~min}$ at $37^{\circ} \mathrm{C}$. The reaction was terminated by adding the stop solution, following which the color changed from blue to yellow. The color change was measured at $450 \mathrm{~nm}$ using a spectrophotometer. Data were calculated according to the following equation: $\mathrm{y}=0.0115 \mathrm{x}+0.1153$ and $\mathrm{R}^{2}=0.9606$.

Assessment of serotonergic genes. Assays were conducted to quantify the expression levels of the following serotonergic receptors: Serotonin 1B receptor (HTR1B), serotonin 2A receptor (HTR2A), serotonin 2B receptor (HTR2B) and serotonin transporter (SLC6A4) under the effects of various drug concentrations of fluoxetine $(1,3,5,7$, and $10 \mu \mathrm{mol} / \mathrm{l})$. Total RNA was extracted from all samples after 5 days of differentiation using an RNA extraction kit (Promega Corporation, Madison, WI, USA). The concentration and quality of extracted RNA were assessed with a Nanophotometer P-330 (Implen $\mathrm{GmbH}$, Munich, Germany). A total of $3 \mu \mathrm{g}$ RNA was reverse transcribed using a SensiFast cDNA Synthesis kit (Bioline Reagents, Ltd., London, UK) according to the manufacturer's protocols. Quantification of mRNA expression levels was performed via reverse transcription-quantitative polymerase chain reaction (RT-qPCR) using the SensiFast SYBR green system (Bioline Reagents, Ltd.). The reaction mixture contained $5 \mu \mathrm{l}$ template cDNA with $1 \mu \mathrm{l}(10 \mathrm{pM})$ forward and reverse primers of the specific genes, and $10 \mu \mathrm{l}$ SYBR green premix, in a total volume of $20 \mu \mathrm{l}$. The thermocycling conditions were as follows: Denaturation at $95^{\circ} \mathrm{C}$ for 2 min followed by 40 cycles of denaturation consisting of $5 \mathrm{sec}$ at $95^{\circ} \mathrm{C}$ and annealing for $30 \mathrm{sec}$ at $55^{\circ} \mathrm{C}$ for HTR $1 \mathrm{~B}, 60^{\circ} \mathrm{C}$ for HTR2A, $53^{\circ} \mathrm{C}$ for HTR2B, $53^{\circ} \mathrm{C}$ for SLC6A4 and $58^{\circ} \mathrm{C}$ for GAPDH and extension at $72^{\circ} \mathrm{C}$ for $10 \mathrm{sec}$. The expression values were measured using the $2^{-\Delta \Delta \mathrm{Cq}}$ method (13) and data were normalized to the loading control gene GAPDH. The primer sequences of the selected genes, as well as the loading control gene, were obtained from NCBI (https://www.ncbi. nlm.nih.gov/nuccore). The forward and reverse sequences are presented in Table I.

Statistical analysis. Data were tabulated and analyzed using SPSS version 23.0 (IBM Corp., Armonk, NY, USA). Data are presented as the mean \pm standard deviation or the median and interquartile range (IQR). All experiments were performed once only. Significant differences were determined by one way analysis of variance, followed by a post-hoc Tukey test for parametric data, and a Kruskal Wallis test was performed for the analysis of non-parametric data. $\mathrm{P}<0.05$ was considered to indicate a statistically significant difference.

\section{Results}

\section{Rat MSCs isolation and characterization}

Cells isolation. Rat MSCs were isolated from $10 \mathrm{~g}$ adipose tissue: $1 \times 10^{6}$ cells/g. At passage 3 , no major morphological alterations were observed during cell passaging. The primary and proliferating cells were fusiform in shape and exhibited fibroblast-like morphologies. The undifferentiated cells were observed to have small bodies with few cell processes, which were long and thin. The cell bodies contained a large, round nucleus with clear appearance (Fig. 1).

Cell characterization. Flow cytometric analysis of cells at passage 3 revealed that cells were positive for CD166, CD105, CD106, anti-Stro-1, CD146, CD44 and CD90. Conversely, the hematopoietic lineage markers, CD45 and CD19 were negative in $>92 \%$ of cells (Fig. 2).

Multilineage differentiation for the determination of osteogenic differentiation. Cells from passage 3 to 7 were used for differentiation; calcium deposits and matrix mineralization 
Table I. Primer sequences of serotonergic genes.

\begin{tabular}{llc}
\hline Gene & \multicolumn{1}{c}{ Forward } & \multicolumn{1}{c}{ Reverse } \\
\hline HTR1B & 5'-GATTGCCACAGTGTACCGGA-3' & 5'-CAGGATGGACACAAGCAGGT-3 \\
HTR2B & 5'-CTCACTGGCTGCCTTCTTCA-3' & 5'-GCGTTGAGGTGGCTTGTT TT-3' \\
HTR2A & 5'-TCGTCATCATGGCAGTGTCC-3' & 5'-ACAAGGAAACCCAGCAGCAT-3' \\
SLC6A4 & 5'-TTGGCTATGCTGTGGACCTG-3' & 5'-TGATGGTGTAGGGGAGGAGG-3' \\
GAPDH & 5'-CTCTGCTCCTCCTGTTCGAC-3' & 5'-GCGCCCAATACGACCAAATC-3'
\end{tabular}

HTR1B, serotonin 1B receptor; HTR2A, serotonin 2A receptor; HTR2B, serotonin 2B receptor; SLC6A4, serotonin transporter.

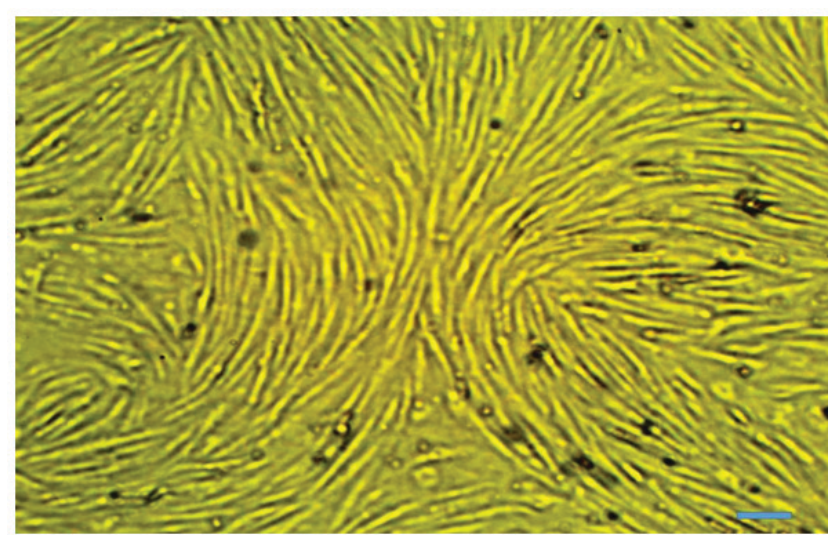

Figure 1. Rat mesenchymal stem cells exhibit fibroblast-like morphology. Cells were analyzed at $90 \%$ confluence and all populations appeared homogenous in shape. Scale bar, $20 \mu \mathrm{m}$.

were detected in the cytoplasm at day 5 using Alizarin red (Fig. 3A). For adipogenic differentiation, cells from passage 3 to 7 were used for differentiation; oil droplets were observed in the cytoplasm after 7 days of differentiation and were clear without staining, however; oil droplets became more evident when stained with Oil Red O (Fig. 3B and C).

Cell treatment with fluoxetine. Various morphological alterations were observed in the treatment groups: Shredding (loss of cellular adherence and integrity), absence of calcium deposits and cluster formations. These alterations were confirmed by flow cytometric analysis of the apoptotic markers caspase- 3 and Annexin V.

Annexin V-FITC detection. There was a significant dose-dependent increase in apoptotic cells in response to increasing doses of fluoxetine. Highly significant late apoptosis was observed in cells treated with $20 \mu \mathrm{mol} / 1$ fluoxetine $(45.2 \pm 6.1 \%)$. The lowest level of apoptosis was observed in cells treated with $5 \mu \mathrm{mol} / 1$ fluoxetine (17.5 $\pm 3.7 \%)$. Data are presented in Fig. 4 .

Caspase-3 detection. Anti-active caspase-3 antibodies were used to quantify the expression of caspase- 3 in the osteoprogenitor cells under the effects of various concentrations of fluoxetine. The number of cells stained positive for caspase-3 was increased in a dose-dependent manner. The highest level of apoptosis was detected in cells treated with $30 \mu \mathrm{mol} / 1$ fluoxetine $(22 \pm 4.5 \%)$. The lowest level of apoptosis was detected in cells treated with $5 \mu \mathrm{mol} / 1$ fluoxetine $(10.6 \pm 2.3 \%)$. Data are presented in Fig. 5.

ELISA analysis of serotonin. The amount of serotonin in the culture supernatants was measured at day 5 for all fluoxetine-treated groups $(1,3,5,7$ and $10 \mu \mathrm{mol} / 1$ fluoxetine) and the control group. Data were expressed as the median and IQR, and a Kruskal Wallis test was used to determine significance (Table II). There was no significant difference in extracellular serotonin concentrations in response to increasing doses of fluoxetine when compared with the control group $(\mathrm{P}=0.098)$.

$R T-q P C R$ analysis of serotonergic genes. The results of RT-qPCR analysis demonstrated that a statistically significant dose-dependent increase in the expression levels of serotonergic receptors, including HTR1B, HTR2A and HTR2B, as well as the serotonin transporter SLC6A4, was detected in osteoprogenitor cells in response to increasing doses of fluoxetine. The expression levels of all receptors were increased in response to $10 \mu \mathrm{mol} /$ fluoxetine and the lowest levels of expression were reported in cells treated with $3 \mu \mathrm{mol} /$ fluoxetine; however, all expression levels were significantly lower compared with the control group $(\mathrm{P}<0.001$; Fig. 6). These results suggested that rat bone cells may exhibit higher expression levels of HTR2A compared with HTR1B and HTR2B in response to fluoxetine.

\section{Discussion}

SSRIs are the most common type of drug used to treat psychiatric disorders and are the first line treatment for major depressive and anxiety disorders (14). Several in vitro studies have reported the presence of serotonin receptors in primary bone cells and/or bone cell lines, which mainly harbor HTR1A, HTR2A and HTR2B binding sites $(4,5)$. Conflicting data have been reported regarding the effects of serotonin and SSRIs on bone; both beneficial and detrimental effects have been observed (15).

In the present study, the effects of fluoxetine on osteoprogenitor cells were investigated using rat adipose tissue-derived MSCs as a source of osteoprogenitor cells. In depth analysis of the effects of fluoxetine on bone cells in vitro was conducted using histochemical analysis with Alizarin red staining. Subsequently, flow cytometric detection of the extent of cell apoptosis was conducted using Annexin V and caspase-3 markers, and the expression levels of serotonin in the cell supernatant were detected in response to various concentrations of 

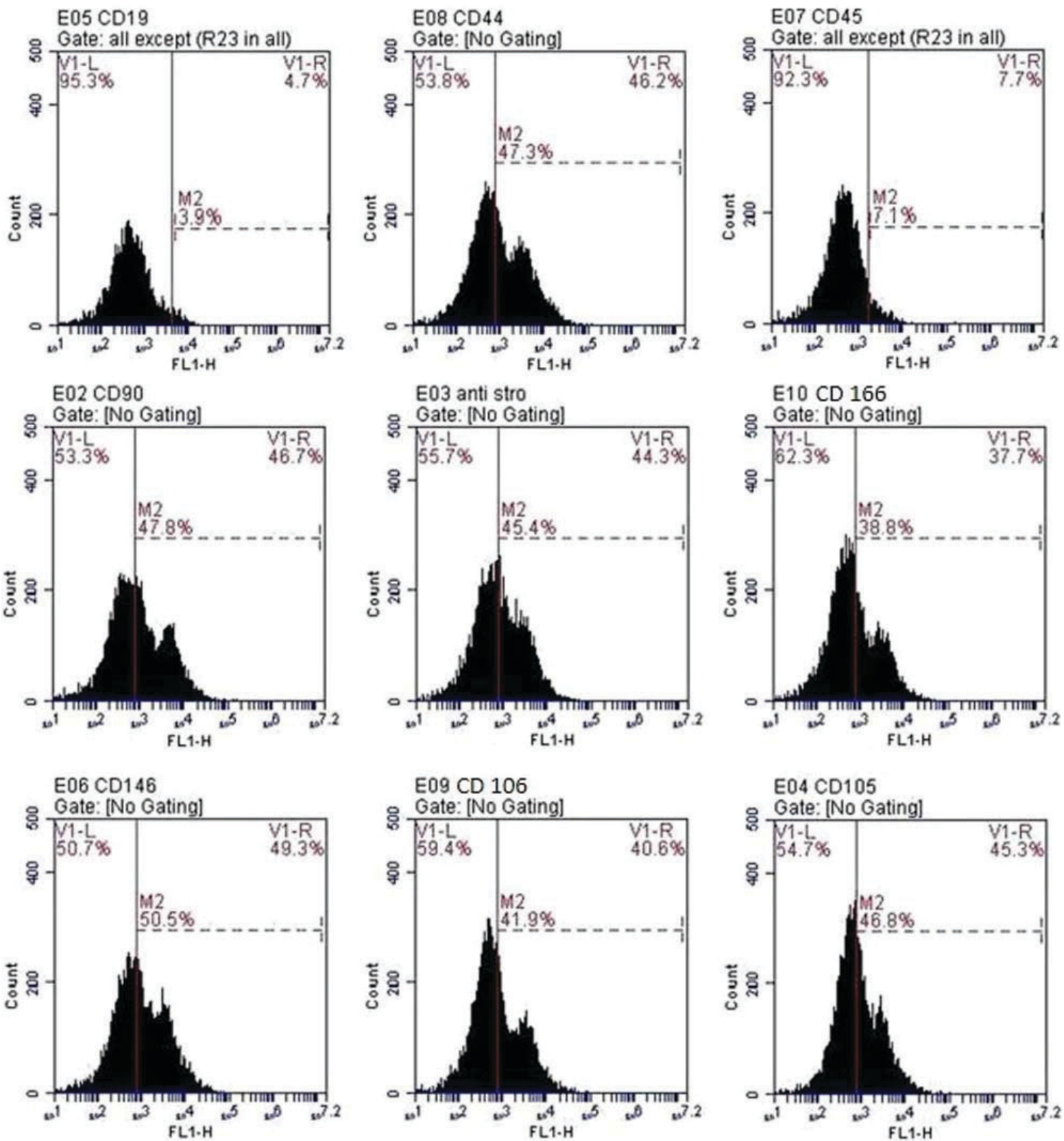

Figure 2. Flow cytometric analysis of rat MSCs. MSCs were positive for CD166, CD105, CD106, anti-Stro-1, CD146, CD44 and CD90, and negative for the hematopoietic markers CD45 and CD19. CD, cluster of differentiation; MSC, mesenchymal stem cell.
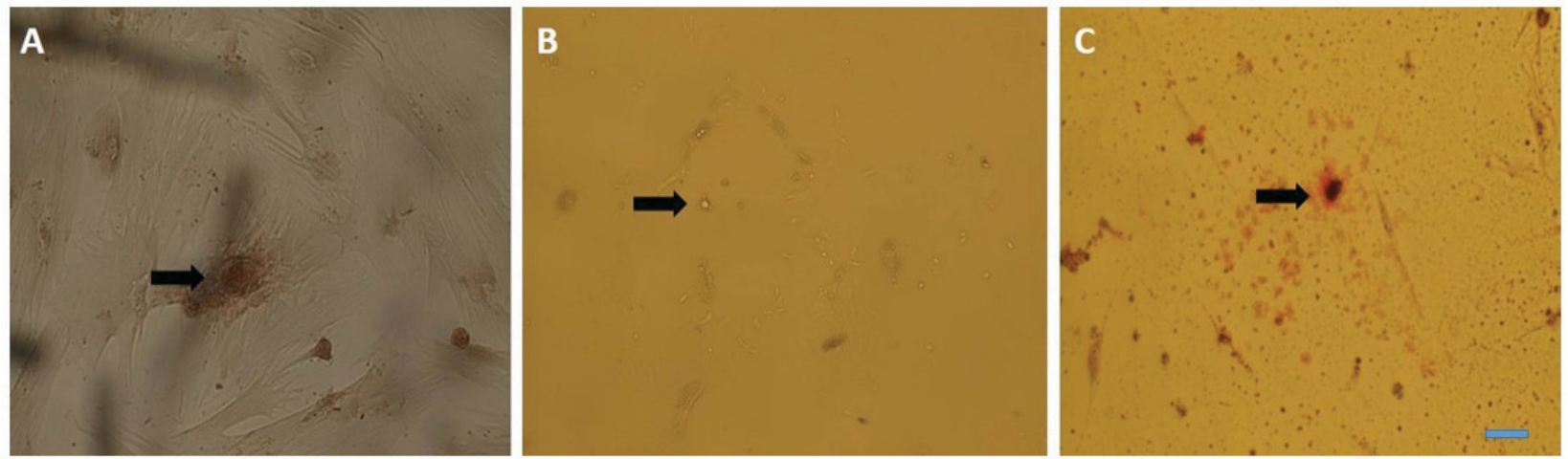

Figure 3. Multilineage differentiation of rat mesenchymal stem cells. (A) Alizarin red staining revealed evident extracellular matrix mineralization and formation of calcium clusters (arrow). (B) Stromal cells following the induction of adipogenic differentiation with evident oil droplets (arrow). (C) Oil red O staining revealed evident oil droplets (arrow) in the extracellular matrix. Scale bar, $20 \mu \mathrm{m}$. 

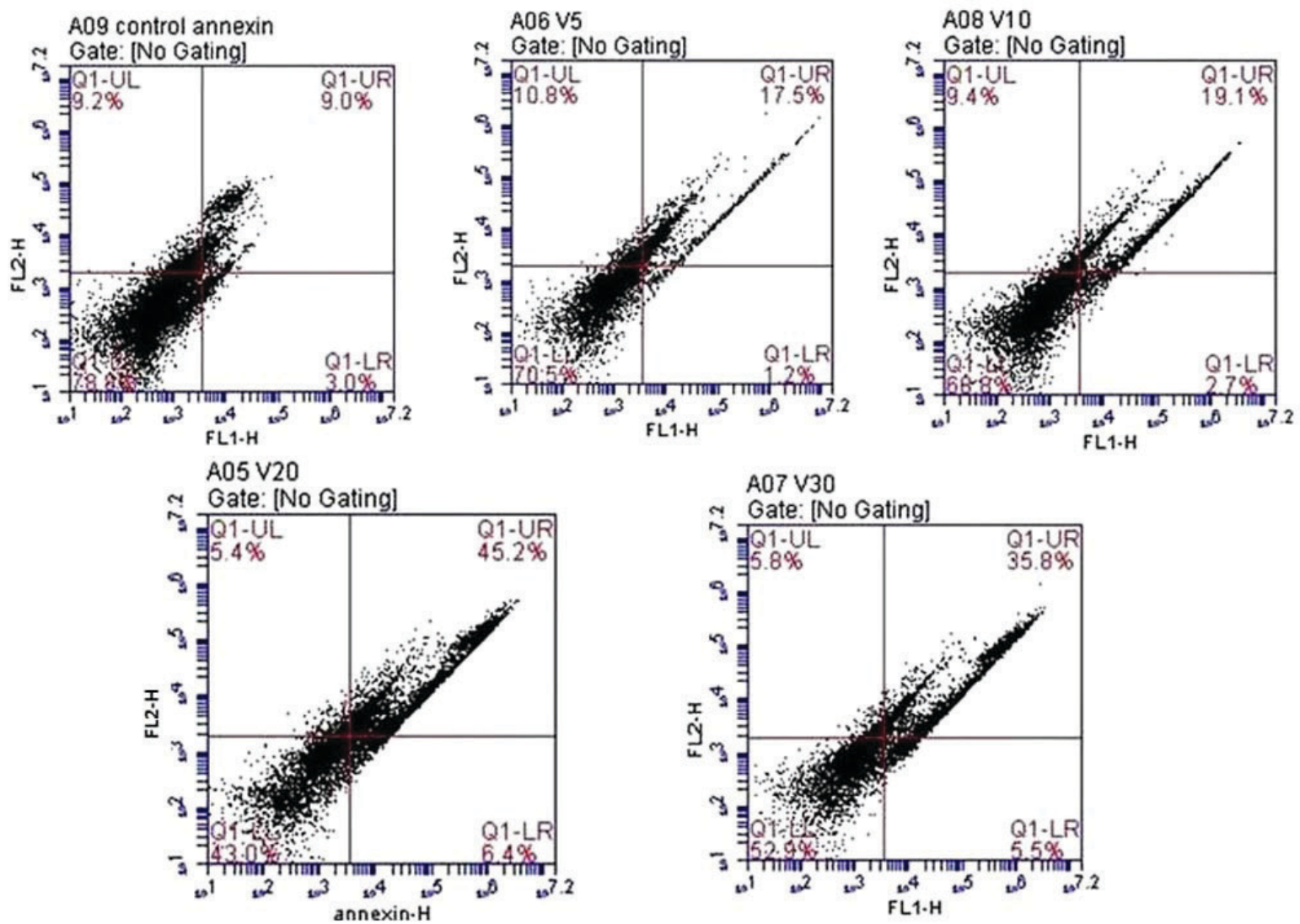

Figure 4. Flow cytometric analysis of apoptosis using Annexin V. V5 refers to $5 \mu \mathrm{mol} / 1, \mathrm{~V} 10$ refers to $10 \mu \mathrm{mol} / 1$, V20 refers to $20 \mu \mathrm{mol} / 1$ and V30 refers to $30 \mu \mathrm{mol} / 1$ fluoxetine. The highest level of apoptosis was detected in cells treated with $20 \mu \mathrm{mol} / 1$ fluoxetine.
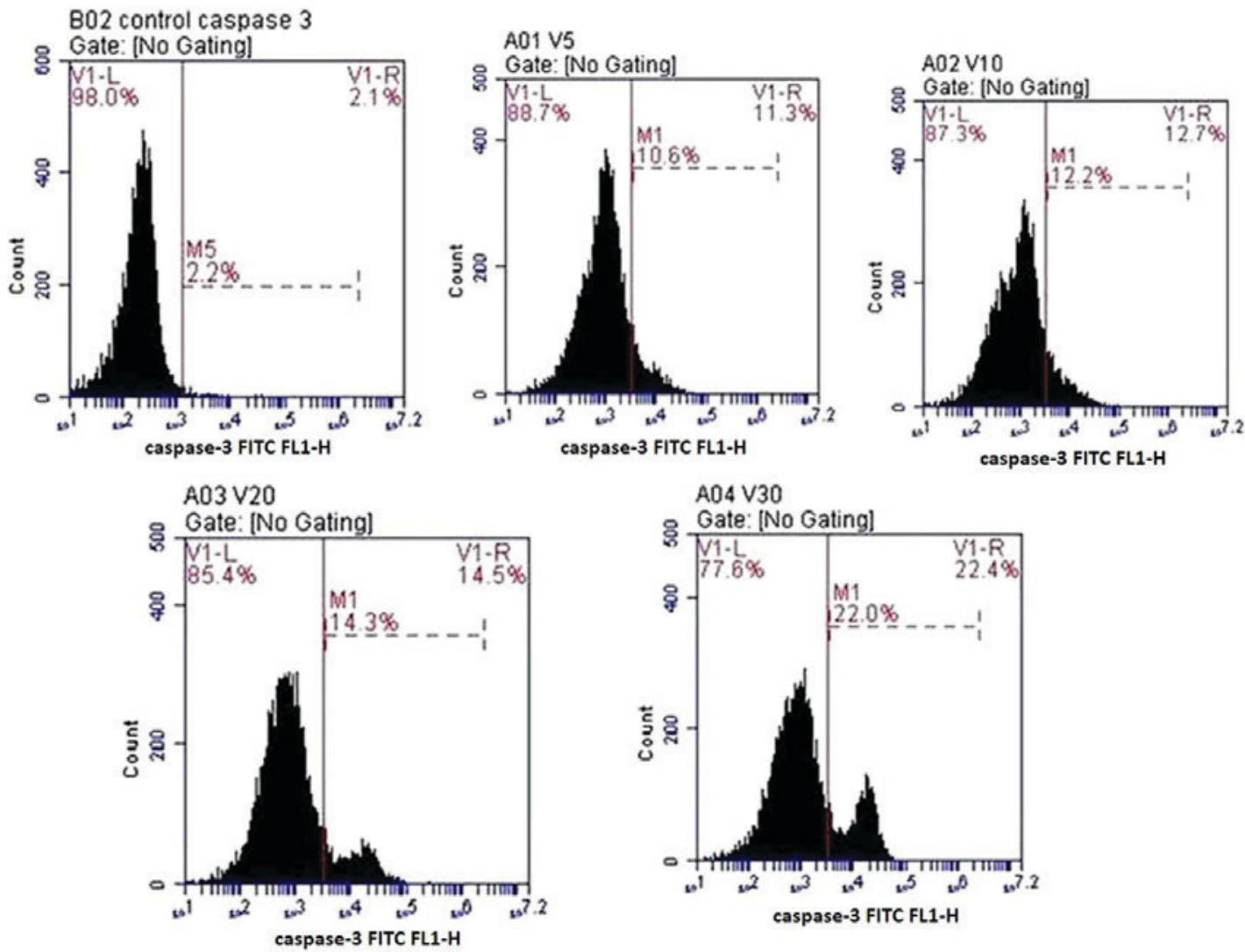

Figure 5. Flow cytometric analysis of apoptosis using caspase-3. V5 refers to $5 \mu \mathrm{mol} / 1$, V10 refers to $10 \mu \mathrm{mol} / 1$, V20 refers to $20 \mu \mathrm{mol} / 1$ and V30 refers to $30 \mu \mathrm{mol} / 1$ fluoxetine. The highest level of apoptosis was detected in cells treated with $30 \mu \mathrm{mol} / 1$ fluoxetine. FITC, fluorescein isothiocyanate. 
Table II. Comparison between serotonin concentrations and increasing doses of fluoxetine.

\begin{tabular}{|c|c|c|c|c|c|c|c|}
\hline & Control group & $1 \mu \mathrm{mol} / 1$ group & $3 \mu \mathrm{mol} / 1$ group & $5 \mu \mathrm{mol} / 1$ group & $7 \mu \mathrm{mol} / 1$ group & $10 \mu \mathrm{mol} / 1$ group & P-value \\
\hline Median & 15.93 & 29.45 & 15.89 & 15.15 & 19.94 & 58 & 0.098 \\
\hline \multirow[t]{2}{*}{ IQR } & 7.082 & 23.63 & 8.941 & 8.256 & 11.06 & 8.800 & \\
\hline & 22.73 & 42.80 & 69.34 & 18.80 & 22.80 & 18.80 & \\
\hline
\end{tabular}

IQR, interquartile range.
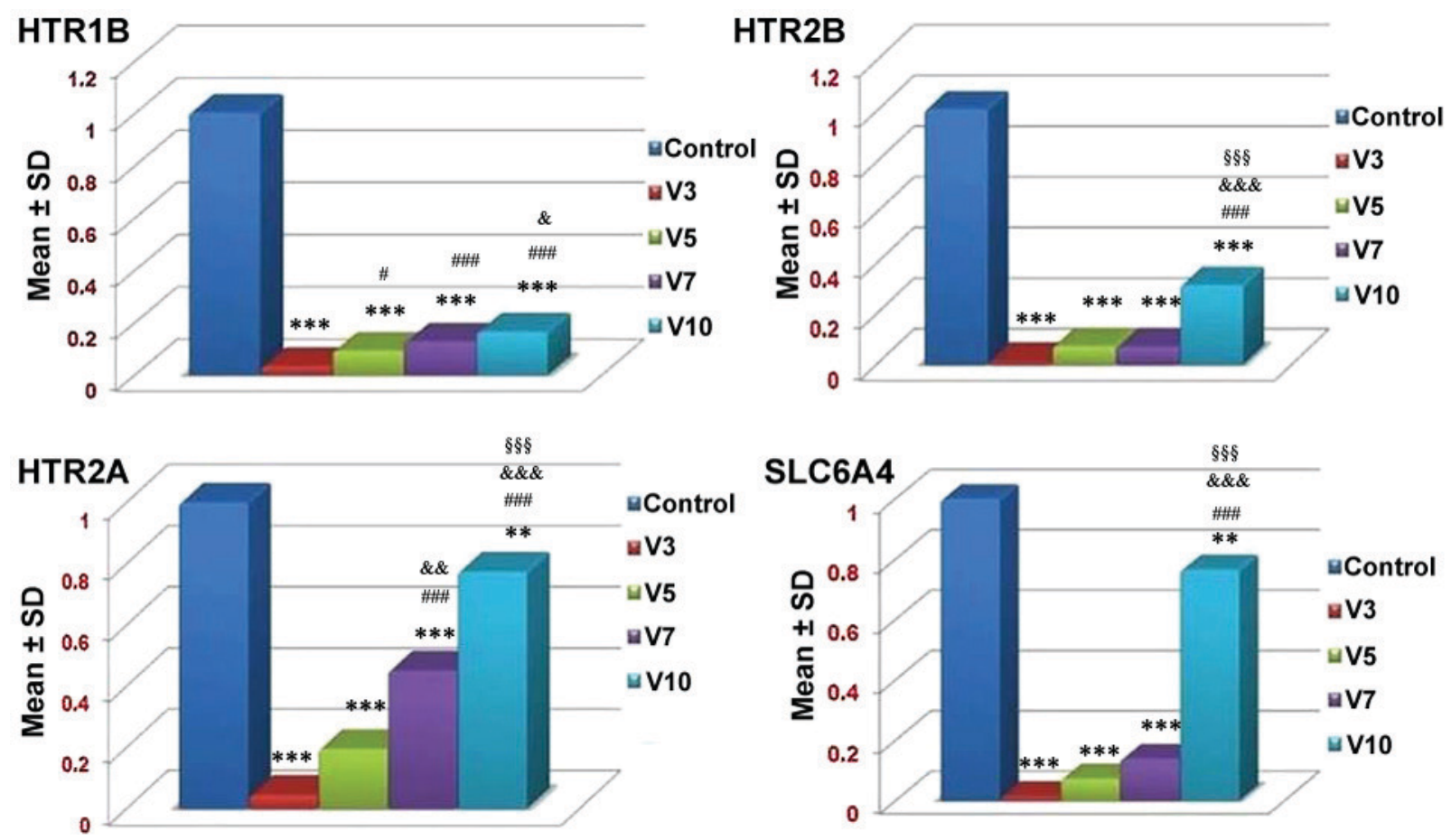

Figure 6. mRNA expression levels of HTR1B, HTR2B, HTR2A and SLC6A4 receptors in the control and fluoxetine-treated groups. Fluoxetine downregulated all investigated serotonergic genes and SLC6A4. V3 refers to $3 \mu \mathrm{mol} / 1$ fluoxetine, V5 refers to $5 \mu \mathrm{mol} / 1$ fluoxetine, V7 refers to $7 \mu \mathrm{mol} / 1$ fluoxetine and V10

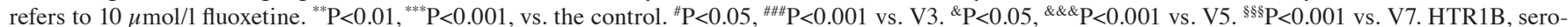
tonin 1B receptor; HTR2A, serotonin 2A receptor; HTR2B, serotonin 2B receptor; SD, standard deviation; SLC6A4, serotonin transporter.

fluoxetine using ELISA. Additionally, RT-qPCR analysis of serotonergic genes was performed to elucidate the underlying molecular pathways associated with the effects of fluoxetine on osteoprogenitor cells.

The results of the present study demonstrated that fluoxetine inhibited osteoprogenitor cell proliferation, differentiation and mineralization in a dose-dependent manner, which may occur via the apoptotic pathway alongside downregulated expression levels of serotonin-associated genes independent of serotonin concentration. Various morphological alterations were reported in cells in response to increasing doses of fluoxetine. Flow cytometric analysis of apoptosis using Annexin V and caspasee-3 markers supported these morphological alterations; increased levels of apoptosis were associated with increasing doses of fluoxetine in the present study. A concentration of $20 \mu \mathrm{mol} / 1$ was associated with cytotoxicity; the proportion of apoptotic cells was $\sim 45.5 \%$ by annexin staining. The present study observed that this cytotoxic effect may be independent of the levels of serotonin within cells. Analysis of intracellular serotonin levels following exposure to various concentrations of fluoxetine indicated that there was an insignificant association between drug dose and the levels of serotonin released. This result supported the hypothesis that apoptosis may be the mechanism underlying the detrimental effects of fluoxetine on osteoprogenitor cells. RT-qPCR analysis detected a significant dose-dependent downregulation of all serotonergic genes, including HTR1A, HTR2A and HTR2B, and SLC6A4. The expression of the HTR2A receptor was the most significantly affected within all treated groups, suggesting an important role of these G-protein coupled receptors on growing bone cells which might need further research work.

The findings of the present study are consistent with those of Hodge et al (16), who conducted a systematic in vitro study investigating the effect of fluoxetine and other SSRIs on trabecular bone cells. In addition, it was reported that treatment of human osteoblasts with increasing doses of exogenous serotonin (3-30 $\mu \mathrm{mol} / \mathrm{l})$ exhibits no effect on bone mineralization or alkaline phosphatase activity (16). However, Ortuño et al (17) revealed the inhibitory effect of fluoxetine on developing bone cells; alternative molecular pathways 
were suggested (17). Ortuño et al (17) identified a dual role of fluoxetine on bone remodeling, in which short-term (3 weeks) treatment with fluoxetine was revealed to result in a local anti-resorptive response that increases bone mass, directly impairing osteoclast differentiation and function via a serotonin reuptake-independent $\mathrm{Ca}^{2+}$-calmodulin-nuclear factor of activated $\mathrm{T}$ cells 1-dependent mechanisms. However, chronic treatment (6 weeks) with fluoxetine was revealed to induce a central serotonin-dependent increase in sympathetic output flow, which results in increased bone resorption sufficient to counteract the local anti-resorptive effects, therefore leading to a net effect of decreased bone formation and bone loss (17).

The present study proposed that fluoxetine induces apoptosis in differentiating bone cells and reduces osteoblasts proliferation (as tested by measuring cell viability), mineralization of the bone cells and the formation of new healthy cells; some studies have indicated that fluoxetine not only inhibits the activity of serotonin but also directly affects cell proliferation and apoptosis in other body tissues: Fluoxetine has been reported to induce apoptosis of the hippocampus and cortical neuronal cells within developing rats as demonstrated by Schaz et al (18).

A recent in vivo study conducted by Rafiei et al (19) investigated the effects of fluoxetine on maxillary teeth in rats by administering fluoxetine $(10 \mathrm{mg} / \mathrm{kg})$ intraperitoneally 5 times/week for 1 month. The results indicated that fluoxetine exerts an inhibitory effect on osteoprogenitor cell regeneration (19). The findings of the present study regarding the effects of fluoxetine on serotonergic genes were consistent with those of Gustafsson et al (20), who reported that stimulation of HTR2A receptors results in reduced signaling for differentiation within osteoblasts. Additionally, it has been reported that the expression levels of HTR2A were higher compared with HTR2B within rat bone cells $(21,22)$. In the present work, it was demonstrated that fluoxetine may have a direct inhibitory effect on the expression of this receptor. To investigate this theory regarding the effect of fluoxetine, more research regarding this point is necessary.

Compared with the findings of the present study, previous reports have demonstrated positive anabolic effects of fluoxetine on bone cells. Battaglino et al (23) demonstrated that treatment of Swiss-Webster mice with fluoxetine at a dose of $10 \mathrm{mg} / \mathrm{kg} / \mathrm{d}$ may stimulate bone formation in the femur and lumbar vertebrae. Mortazavi et al (24) reported an increase in bone formation following treatment with fluoxetine of rats with calvarial small-size bone defects. A possible explanation for this difference in results may be the variation in the fluoxetine treatment protocol, using different strains of animals or genetic differences in the origin of the tested cells. The results of Nam et al (22) were in accordance with those of the present study regarding the inhibitory effects of fluoxetine on bone cells, however; serotonin was proposed to exhibit a direct inhibitory effect on osteoprogenitor cells (22), contradictory to the results of the present study.

In conclusion, the present study demonstrated a direct inhibitory effect of fluoxetine on bone cells, which may be dependent on apoptosis rather than on serotonin levels. Additionally, there was an overall down regulation in the expression of serotonin receptors HTR1B, HTR2A, HTR2B as well as 5HTTT (SLC6A4) in response to varying doses of fluoxetine. The findings of the present study may indicate that fluoxetine consumption negatively affects bone mineral density with the possible increase in the rate of bone fracture.

\section{Acknowledgements}

Not applicable.

\section{Funding}

The present study was supported by funding from Mansoura University competitive grants program (MAS, MS, 2015) and International Society for Neurochemistry (ISN) CAEN grant 2017. Category 1B (MS).

\section{Availability of data and materials}

The datasets used and/or analyzed during the current study are available from the corresponding author on reasonable request.

\section{Authors' contributions}

MS, AL and MAS designed the study; SMK, MS and MEH performed the experiments; SMK, MS, MEH, MESAK, AL, SAH, SAGE and MAS performed data analysis; and, SMK, MS and MEH wrote the manuscript.

\section{Ethics approval and consent to participate}

The protocol conducted in the present study was approved by the medical ethical committee of the Faculty of Medicine, Mansoura University (Mansoura, Egypt).

\section{Patient consent to participate}

Not applicable.

\section{Competing interests}

The authors declare that they have no competing interests.

\section{References}

1. Haney EM, Chan BK, Diem SJ, Ensrud KE, Cauley JA, Barrett-Connor E, Orwoll E, Bliziotes MM and Osteoporotic Fractures in Men Study Group: Association of low bone mineral density with selective serotonin reuptake inhibitor use by older men. Arch Intern Med 167: 1246-1251, 2007.

2. Haney EM, Warden SJ and Bliziotes MM: The effects of selective serotonin reuptake inhibitors on bone health in adults: Time for recommendations about screening, prevention and management?. Bone 46: 13-17, 2010.

3. Chen F, Hahn TJ and Weintraub NT: Do SSRIs play a role in decreasing bone mineral density? J Am Med Dir Assoc 13: 413-417, 2012.

4. Bliziotes MM, Eshleman AJ, Zhang XW and Wiren KM: Neurotransmitter action in osteoblasts: Expression of a functional system for serotonin receptor activation and reuptake. Bone 29: 477-486, 2001

5. Westbroek I, van der Plas A, de Rooij KE, Klein-Nulend J and Nijweide PJ: Expression of serotonin receptors in bone. J Biol Chem 276: 28961-28968, 2001.

6. Chau K, Atkinson SA and Taylor VH: Are selective serotonin reuptake inhibitors a secondary cause of low bone density? J Osteoporos 2012: 323061, 2012.

7. Bab I and Yirmiya R: Depression, selective serotonin reuptake inhibitors, and osteoporosis. Curr Osteoporos Rep 8: 185-191, 2010. 
8. Bradaschia-Correa V, Josephson AM, Mehta D, Mizrahi M Neibart SS, Liu C, Kennedy OD, Castillo AB, Egol KA and Leucht P: The selective serotonin reuptake inhibitor fluoxetine directly inhibits osteoblast differentiation and mineralization during fracture healing in mice. J Bone Miner Res 32: 821-833, 2017.

9. Zuk PA, Zhu M, Ashjian P, De Ugarte DA, Huang JI, Mizuno H, Alfonso ZC, Fraser JK, Benhaim P and Hedrick MH: Human adipose tissue is a source of multipotent stem cells. Mol Biol Cell 13: 4279-4295, 2002.

10. Zimmerlin L, Donnenberg VS and Donnenberg AD: Rare event detection and analysis in flow cytometry: Bone marrow mesenchymal stem cells, breast cancer stem/progenitor cells in malignant effusions, and pericytes in disaggregated adipose tissue. Methods Mol Biol 699: 251-273, 2011.

11. Halvorsen YD, Franklin D, Bond AL, Hitt DC, Auchter C, Boskey AL, Paschalis EP, Wilkison WO and Gimble JM: Extracellular matrix mineralization and osteoblast gene expression by human adipose tissue-derived stromal cells. Tissue Eng 7: 729-741, 2001.

12. Salamh M, Mehanna R, Hanafy Sh and Abdel Ghafar H: The usage of liver extract verses growth factors in the differentiation of mesenchymal stem cells into hepatocyte like cells. J Int Acad Res Multidisciplinary 2: 35-50, 2014.

13. Livak KJ and Schmittgen TD: Analysis of relative gene expression data using real-time quantitative PCR and the 2(-Delta Delta C (T)) method. Methods 25: 402-408, 2001.

14. Dale E, Bang-Andersen B and Sánchez C: Emerging mechanisms and treatments for depression beyond SSRIs and SNRIs. Biochem Pharmacol 95: 81-97, 2015.

15. Tsapakis EM, Gamie Z, Tran GT, Adshead S, Lampard A, Mantalaris A and Tsiridi E: The adverse skeletal effects of selective serotonin reuptake inhibitors. Eur Psychiatry 27: 156-169, 2012.

16. Hodge JM, Wang Y, Berk M, Collier FM, Fernandes TJ, Constable MJ, Pasco JA, Dodd S, Nicholson GC, Kennedy RL and Williams LJ: Selective serotonin reuptake inhibitors inhibit human osteoclast and osteoblast formation and function. Biol Psychiatry 74: 32-39, 2013.
17. Ortuño MJ, Robinson ST, Subramanyam P, Paone R, Huang YY, Guo XE, Colecraft HM, Mann JJ and Ducy P: Serotonin-reuptake inhibitors act centrally to cause bone loss in mice by counteracting a local anti-resorptive effect. Nat Med 22: 1170-1179, 2016

18. Schaz U, Föhr KJ, Liebau S, Fulda S, Koelch M, Fegert JM, Boeckers TM and Ludolph AG: Dose-dependent modulation of apoptotic processes by fluoxetine in maturing neuronal cells: An in vitro study. World J Biol Psychiatry 12: 89-98, 2011.

19. Rafiei M, Sadeghian S, Torabinia N and Hajhashemi V: Systemic effects of fluoxetine on the amount of tooth movement, root resorption, and alveolar bone remodeling during orthodontic force application in rat. Dent Res J (Isfahan) 12: 482-487, 2017.

20. Gustafsson BI, Westbroek I, Waarsing JH, Waldum $\mathrm{H}$, Solligård E, Brunsvik A, Dimmen S, van Leeuwen JP, Weinans H and Syversen U: Long-term serotonin administration leads to higher bone mineral density, affects bone architecture, and leads to higher femoral bone stiffness in rats. J Cell Biochem 97: 1283-1291, 2006.

21. Dai SQ, Yu LP, Shi X, Wu H, Shao P, Yin GY and Wei YZ: Serotonin regulates osteoblast proliferation and function in vitro. Braz J Med Biol Res 47: 759-765, 2014.

22. Nam SS, Lee JC, Kim HJ, Park JW, Lee JM, Suh JY, Ums HS, Kim JY, Lee Y and Kim YG: Serotonin inhibits osteoblast differentiation and bone regeneration in rats. J Periodontol 87: 461-469, 2016.

23. Battaglino R, Vokes M, Schulze-Späte U, Sharma A, Graves D, Kohler T, Müller R, Yoganathan S and Stashenko P: Fluoxetine treatment increases trabecular bone formation in mice. J Cell Biochem 100: 1387-1394, 2007.

24. Mortazavi SH, Khojasteh A, Vaziri H, Khoshzaban A, Roudsari MV and Razavi SH: The effect of fluoxetine on bone regeneration in rat calvarial bone defects. Oral Surg Oral Med Oral Pathol Oral Radiol Endod 108: 22-27, 2009.

This work is licensed under a Creative Commons Attribution-NonCommercial-NoDerivatives 4.0 International (CC BY-NC-ND 4.0) License. 